\title{
Gender Differentiation in the Chinese Language
}

\section{Çin Dilinde Cinsiyet Ayrımı}

\author{
Cansu GÜMÜŞ ${ }^{1}$
}

'Boğaziçi University, Graduate Program in Asian Studies, Istanbul Turkey

\section{ORCID: C.G. 0000-0001-5880-9978}

Corresponding author/Sorumlu yazar: Cansu GÜMÜŞ (M.A. Student)

Boğaziçi University, Graduate Program in Asian Studies, Istanbul Turkey

E-mail: jiangsu1227@gmail.com

Submitted/Başvuru: 31.10 .2020

Revision Requested/Revizyon Talebi:

18.02.2021

Last Revision Received/Son Revizyon:

26.03.2021

Accepted/Kabul: 27.03.2021

Citation/Atıf: Gumus, Cansu. "Gender

Differentiation in the Chinese Language".

Şarkiyat Mecmuas। - Journal of Oriental Studies 38 (2021), 25-36

https://doi.org/10.26650/jos.819113

\begin{abstract}
Language is one of the most important factors affecting the formation of perceptions, thoughts and behaviors about gender in society. In China, studies on the relationship between gender and language began after the 1980s. The Chinese language, which evolved from pictograms, does not have any prefixes or suffixes indicating gender. However, even though Chinese grammatically does not seem like a sexist language, this does not mean that Chinese is a language that does not demonstrate gender discrimination or classification. Gender discrimination can be reflected in the language in different ways. This article will attempt to answer the question: "How is the inferior position of Chinese women in society reflected in language?" To answer this question, gender discrimination in the Chinese language will be evaluated in terms of Chinese word formation, idioms, proverbs, word order and the third-person singular pronoun. With this objective in mind, this research refers to a Chinese dictionary and uses recent findings about this issue to source the words relating to gender, specifically women. Before analyzing the examples in the Chinese language, it will be beneficial to give a brief background on what kind of language Chinese is. Then, some examples of gender related words, especially consisting of the character 女 (nü-woman, female), pronouns, proverbs and idioms will be given and examined.
\end{abstract}

Keywords: Chinese Language, Gender, Women, Discrimination, Differentiation

\section{ÖZ}

Dil, toplumda cinsiyet ile ilgili algı, düşünce ve davranışların oluşumunu etkileyen en önemli faktörlerden biridir. Çin'de cinsiyet ve dil arasındaki ilişki üzerine yapılan çalışmalar 1980'lerden sonra başlamıştır. Resim yazısından gelişen Çin dilinde cinsiyet farklılığı belirten herhangi bir ön ek ya da son ek bulunmamaktadır. Fakat Çince, dilbilgisi açısından cinsiyetçi bir dil gibi görünmese de bu durum Çincede cinsiyet ayrımcılığı ya da cinsiyet sınıflandırması olmadığı anlamına gelmemektedir. Cinsiyet ayrımcılığı dile farklı şekillerde yansıtılabilir. Bu makale "Çinli kadınların toplumdaki ikincil konumları dile nasıl yansıtılmaktadır?" sorusuna cevap vermeye çalışacaktır. Bu sorunun cevaplanabilmesi için Çincedeki cinsiyet ayrımcılığı Çince kelimelerin oluşumu, deyimler, atasözleri, kelime sıralaması ve üçüncü tekil şahıs zamiri açısından değerlendirilecektir. Bu amaçla cinsiyetle ilgili özellikle kadınla ilgili kelimeleri bulmada Çince sözlükten ve bu konuda 
yapılan son araştırmalardan yararlanılacaktır. Çincedeki örnekleri incelemeden önce, Çincenin ne tür bir dil olduğu hakkında kısa bir bilgi vermek faydalı olacaktır. Daha sonra, özellikle 女 (nü-kadın, dişi) karakterini içeren kelimeler, zamirler, atasözleri ve deyimlerden oluşan cinsiyetle alakalı bazı örnekler verilecek ve incelenecektir.

Anahtar kelimeler: Çince, Cinsiyet, Kadın, Ayrımcılık, Farklılaştırma 


\section{Introduction}

Chinese society is a patriarchal society based on male domination. In this male-dominated society, women are often humiliated and viewed as second-class citizens. Obedience is the main indicator of this and dictates whether a woman is viewed as "good" or "bad". Confucianism places basic requirements for being a good woman with "Three Obediences and Four Virtues" (三从四德-Sāncóngsìdé). The “Three Obediences” are “obey your father before marriage (未 嫁从父-Wèi jià cóng fù); obey your husband when married (既嫁从夫-Jijiàcóngfū); and obey your sons in widowhood (夫死从子-Fūš̌zòngzî)". And the "Four Virtues" are "female virtues (妇德-Fùdé), female words (妇言-Fùyán), female appearances (妇容-Fùróng) and female work (妇功-Fùgōng)". In the book Lessons for Women (女诫-Nüjiè) written by Ban Zhao, one of the first known female historians in China, she clearly demonstrates how young women should conduct themselves and serve their in-laws. ${ }^{1}$ In addition to Confucian philosophy, Lessons For Women (女诫) also helps to perpetuate the secondary place of women in Chinese society. Once the place of a woman in society is formed, gender differentiation is solidified. This situation is also clearly seen in the following excerpts from the Book of Poetry (诗经- Shījīng): ${ }^{2}$

Sons shall be born to him:

They will be put to sleep on couches;

They will be clothed in robes;

They will have scepters to play with...

Daughters shall be born to him:

They will be put to sleep on the ground;

They will be clothed with wrappers;

They will have tiles to play with.

It will be theirs neither to do good nor to do wrong;

Only about the spirit and the food will they have to think,

And to cause no sorrow to their parents.

As demonstrated above, there are many examples of gender differentiation in Chinese philosophy and literature, which raises the questions: Are there examples of gender differentiation in the Chinese language? Does the Chinese language define women as inferior in society?

In ancient times, tribes were dominated by women. Even the Chinese character for the family name, xing 姓, is composed of the characters for female 女 (nü) and birth 生 (sheng), which attests to the matriarchal origin of the family. ${ }^{3}$ As this example shows, Chinese characters

1 Angela Jung-Palandri, "Gender and Sexism in Chinese Language and Literature", Sino-Platonic Papers, 27(1991), p. 168.

2 Ibid., 167.

3 Ibid., 167. 
can express and conduct gender-related messages. This article aims to explore how gender differentiation is constructed and reflected through the Chinese language. With this aim, it will investigate how men and women are presented in the Chinese language. First of all, what kind of language Chinese is will be analyzed.

\section{Chinese Language}

The Chinese language is one of the oldest languages in the world, and has over a billion speakers. Unlike western languages, it evolved from pictograms, not letters. In terms of gender, there is no prefix or suffix that indicates gender in Chinese grammar. Whorf classifies languages as overt and covert classes. The fact that Chinese is grammatically genderless does not mean that there is no gender discrimination within the language. It is in fact portrayed through words, symbols, pronouns, proverbs and idioms, which is why Whorf includes Chinese among the covert class languages. ${ }^{4}$ Before examining in detail how this distinction is made, it will be useful to analyze how Chinese characters are formed. There are six kinds of Chinese characters:

1. 象形 (xiàng xíng) Pictographs: They are created from historical pictures. As you can see, the character 山 is a visual representation of a mountain.

2. 指事 (zhǐ shì) Ideographs: They are the characters used to express abstract things. For example: Numbers (一,二,三) and directional characters such as 上下.

3. 形声 (xíng shēng) Determinative-Phonetic Characters: These characters are a combination of pictogram and phonetic. For example:

$\begin{array}{lll}\vdots+ & \text { 其 }= & \text { 淇 } \\ \text { Shui } & \text { qi } & \text { qi } \\ \text { (water) } & \text { (his/her/its) } & \text { (river) }\end{array}$

4. 会意 (huì yì) Combined Ideographs: A new word is formed by the combination of two or more pictographs or ideographs. For example, the character for "man" is composed of the following two characters: rice field 田 (tián) and strength 力 (li), as men need strength in the fields. This example shows not only that a new character was created, but also that a masculine feature was added to the character.

5. 转注 (zhuăn zhù) Transfer Characters: If some characters share the same semantic radicals, these characters could be interchangeable with each other. For example: 爸 (bà) -父 (fü). Both characters mean 'father' and can be used interchangeably.

6. 假借 (jiă jiè) Loan Characters: It means that the character, which previously meant something else, loses its original meaning and takes on a new meaning. For example, 来 lái used to mean 'flour', but now it means 'to come'. 5

4 Catherine S. Farris, "Gender and Grammar in Chinese With Implications for Language Universals", Modern China, 1988, p. 278.

5 Giray Fidan, Çin Dili ve Çince Dilbilgisi, Ankara: Efil Yayınevi,2011, p. 13. 


\section{Literature Review}

Since 1970, there have been many studies on language and gender that have been published in the USA. ${ }^{6}$ Arguably, the most important year for studies in the West was 1975. Robin Lakooff, Thorne and Henley and Key all published books in this year. ${ }^{77}$ However, during this time, language and gender studies in China remained dormant compared to the West. The first notable studies in China were conducted by Timothy Light (1982), Yu-Huei Shih (1984), and Catherine Farris (1988). These studies have paved the way for further studies on language and gender studies. Dali Tan (1990), Carol C. Fan (1996), David Moser (1997), Charles Ettner (2002), Huang (2009) and Huang (2011) are some of the other major scholars who studied Chinese proverbs, idioms, pronouns and the female character “女 (nü)" relative to gender and language. In light of these studies, the relationship between Chinese and gender will be examined.

\section{1- Female Character 女 (nü) in Word Formation}

In order to form a Chinese word, Chinese characters are formulated by compounding graphs and radicals. There are about 250 characters that contain the “女 (nü)" character. ${ }^{8}$ This section mainly will focus on the words that form negative and positive connotations towards the female character 女 (nü). In a study based on the Modern Chinese Dictionary, 178 words with 女 (nü) characters were examined. As a result of this examination, some of these words have been shown to indicate kinship relations to women (姑 gū 'aunt', 姐 jiě 'sister', 嫂 săo 'sister-in-law'), some indicate family names (姜 Jiāng, 宴 Yàn), and some of them serve to produce new characters that seem semantically unrelated to the female character at first glance, like 始 shí (beginning). Upon further examination, however, it can be seen that more than one sixth of these female compound words are associated with negative meanings. ${ }^{9}$ Some of these characters are below:

奸 (jiān)- treacherous

嫌 (xián)- suspicion

婉 (jí)- jealous

奴 (nú)- slave

妖 (yāo)- evil spirit

怒 (nù)- angry

妄 (wàng)- arrogant

6 Marjorie K.M. Chan, "Gender Differences in the Chinese Language: A Preliminary Report", NACCL-9, 1997, p. 35 .

7 "Gender-specific Asymmetries in Chinese Language", MP: An Online Feminist Journal, 2008, p. 31

8 Carol C. Fan, "Language, Gender and Chinese Culture", International Journal of Politics, Culture and Society, 10/1 (1996), p. 97.

9 "Gender-specific Asymmetries in Chinese Language", MP: An Online Feminist Journal, 2008, p. 35. 


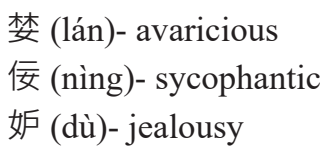

As can be understood from these adjectives with derogatory meanings which use the 女 (nü) character, bad moral values are associated with women.
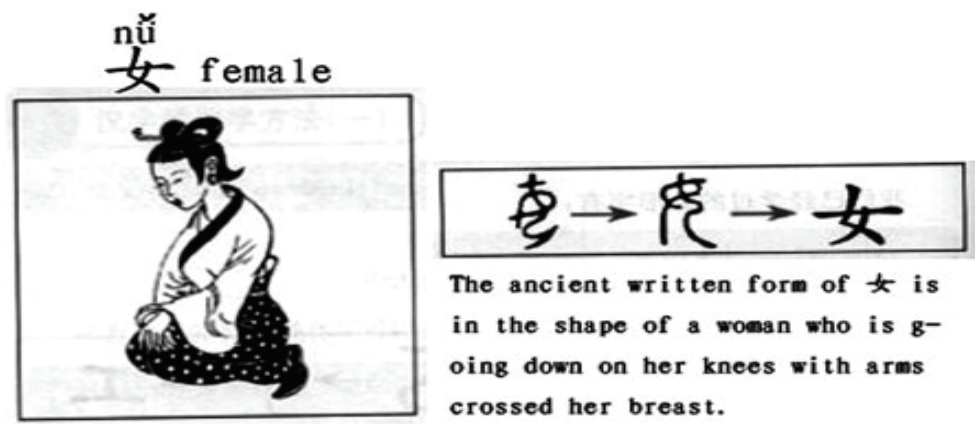

Figure 1: The pictograph of the female character 女(nü) Retrieved from http://www.hanban.com/writing-chinese/characters/ traditional-chinese-character.html

In oracle bone inscriptions the female character 女(nü) consists of a pictographic representation of a person kneeling down with her arms lowered and hands clasped on her lap. ${ }^{10}$ Since its formation, then, we can see that this character has put women in an inferior position. The character for wife 妇 (fù), consists of a female 女 (nü) holding a broom. ${ }^{11}$ This signifies the duty to do housework. ${ }^{12}$ In contrast, the character for "man" is composed of the two characters: rice field 田 (tián) and strength 力 (li). This clearly shows that the woman is associated with sweeping the floor while her husband represents authority. There are two different characters that mean 'getting married' for men and women. The character for a man 娶 (qǔ) is formed with the combination of the characters 取 (qǔ-to take) and 女 (nü-woman). So, marriage for a man means to 'take a woman'. However, the character for a woman 嫁 (jià) is formed by combining the characters 女 (nü-woman) and 家 (jiā-family). Thus, marriage for a woman means to 'go to a husband's family'. The character 嫁 (jià) clearly demonstrates us the patrilocality in China.

After marriage under her husband's roof, the wife's condition is identified as being pleased

10 Jianhsin Wu, "Basic Radicals", In the Way of Chinese Characters, retrieved from https://www.cheng-tsui.com/ sites/default/files/previews/Way\%20of\%20Chinese\%20Characters_2E_Sample.pdf(Accessed on 10 September 2020).

11 Dali Tan, "Sexism in the Chinese Language", NWSA Journal, 2/4 (1990), p. 636.

12 Carol C. Fan, "Language, Gender and Chinese Culture", International Journal of Politics, Culture and Society, 10/1 (1996), p. 96. 
and is represented by the character 安 (ān). The character 安 (ān) is formed using a combination of the characters 女 (nü-woman) and 它 (mián-roof). This character is also interpreted as when a woman is in the house, there is peace (安-ān). ${ }^{13}$ Moreover, the character 好 (hăo), which is composed of the characters of a woman (女-nü) and a son/child (子-ž̌), means 'good'. Thus, a connection can be made between a woman with a child and the word "good", and it can be said that childbearing is one of the basic functions attributed to women. ${ }^{14}$

The characters 如 (obedience), 安 (safe), 嫁 (marry), and 好 (good) all reflect cultural belief relating to women. According to these characters, women should stay at home and give birth to a child. Having children is seen as a sign that they are a good wife. It would not be wrong to say that all these characters are reflections of a patriarchal society.

When children learn these characters, they can unintentionally make a fundamental connection between these characters and the female gender. This situation unknowingly gives rise to and creates a perception for children that women are less valuable, and that they are subordinate to their husbands.

\section{2- Gender Related Order in Expressions}

In the Chinese language many expressions are arranged in the defined ordering of male first and female second. The problem here is that in most oppositional and collocational dyads, the first one is perceived as positive and primary while the second one is thought of as negative and less important. ${ }^{15}$ For example: 对错 (duì cuò-correct-incorrect), 上下 (shàngxiàup down), 高低 (gāodī-high low), 爱恨 (ài hèn-love hate). ${ }^{16}$ Farris suggested that syntactic ordering would encourage sexism by putting women in a secondary position. ${ }^{17}$ The following examples illustrate male-female word order in Chinese:

\section{Chinese Character}

男女 (nánnü)

父母 (fùmǔ)

爸妈 (bàmā)

夫妻 (fūqī)

夫妇 (fūfù)

母女 (mǔnü)

\begin{abstract}
Meaning
Men and women

Father and mother

Father and mother

Husband and wife

Husband and wife

Mother and daughter
\end{abstract}

13 Katarzyna Bańka, Gender in Written and Spoken Chinese Language: When the Words Are Masculine and When Feminine?, Frontiers of Language and Teaching, 2015, p. 56.

14 Angela Jung-Palandri, "Gender and Sexism in Chinese Language and Literature",Sino-Platonic Papers, 27(1991), p. 169.

15 Wing B. A.Tso, "Masculine Hegemony and Resistance in Chinese Language", Writing from Below, 2/1 (2014), p. 6.

16 Ibid., 6.

17 Catherine S.Farris, "Gender and Grammar in Chinese: with implication for language universals", Modern China, 14/3 (1988), pp. 277-307. 


$\begin{array}{ll}\text { 子女 (zinü) } & \text { Son and daughter } \\ \text { 儿女 (érnü) } & \text { Son and daughter } \\ \text { 龙凤 (lóngfèng) } & \begin{array}{l}\text { Dragon-phoenix, which symbolizes male and female } \\ \text { respectively }\end{array} \\ \text { 乾坤 (qiánkūn) } & \text { Heaven-earth, which symbolizes male and female } \\ & \text { respectively } \\ \text { 兄弟姐妹 (xiōngdì jiěmèi) } & \text { Brothers and sisters }\end{array}$

When looking at and analyzing these words, it is clear that there is hierarchical ordering. In other words, gender and age play a key role in determining the order for these expressions. The expressions of 男女, 父母, 爸妈, 夫妻, 夫妇, 子女, 儿女 are also good examples of women seen in a secondary place or position. The ordering of the expression of $母$ 女 (mother and daughter) and 兄弟姐妹 (brothers and sisters) shows that not only gender but also age is a determinant for syntax. In her article entitled Gender Differences in the Chinese Language, Chan argued that semantic is not the only basis for word ordering, but also is important for the "four tones". However, when we look at the examples like 夫妻 (fūqī) and 夫妇 (fūfù), it is clear that both characters are the same tone. Therefore, semantic ordering plays a key role.

If the position of the characters were to be reversed, the expressions would appear strange or wrong, for example 女男 (nünan) sounds incorrect. In addition, when the order of the 儿女 (ernü-son and daughter) expression is changed, another expression and a different meaning emerges. (女儿; nǚer-daughter)

\section{3- Gender Differentiation in Idioms and Proverbs}

Proverbs and idioms are rich cultural expressions that reflect the attitudes and thoughts of societies. They contain basic collective beliefs and stereotypes, having been passed down from generation to generation for many years. ${ }^{18}$ In this section, proverbs and idioms about women will be examined and the perception of women in the society will be discussed.

According to a survey conducted in 2002, ${ }^{19} 42$ students, of whom more than half were female, were required to write at least two gender-related proverbs with fixed expressions. The most frequently written examples are shown in table 1, in order of frequency.

18 "Gender-specific Asymmetries in Chinese Language", MP: An Online Feminist Journal, 2008, p. 38.

19 Ibid., 39. 


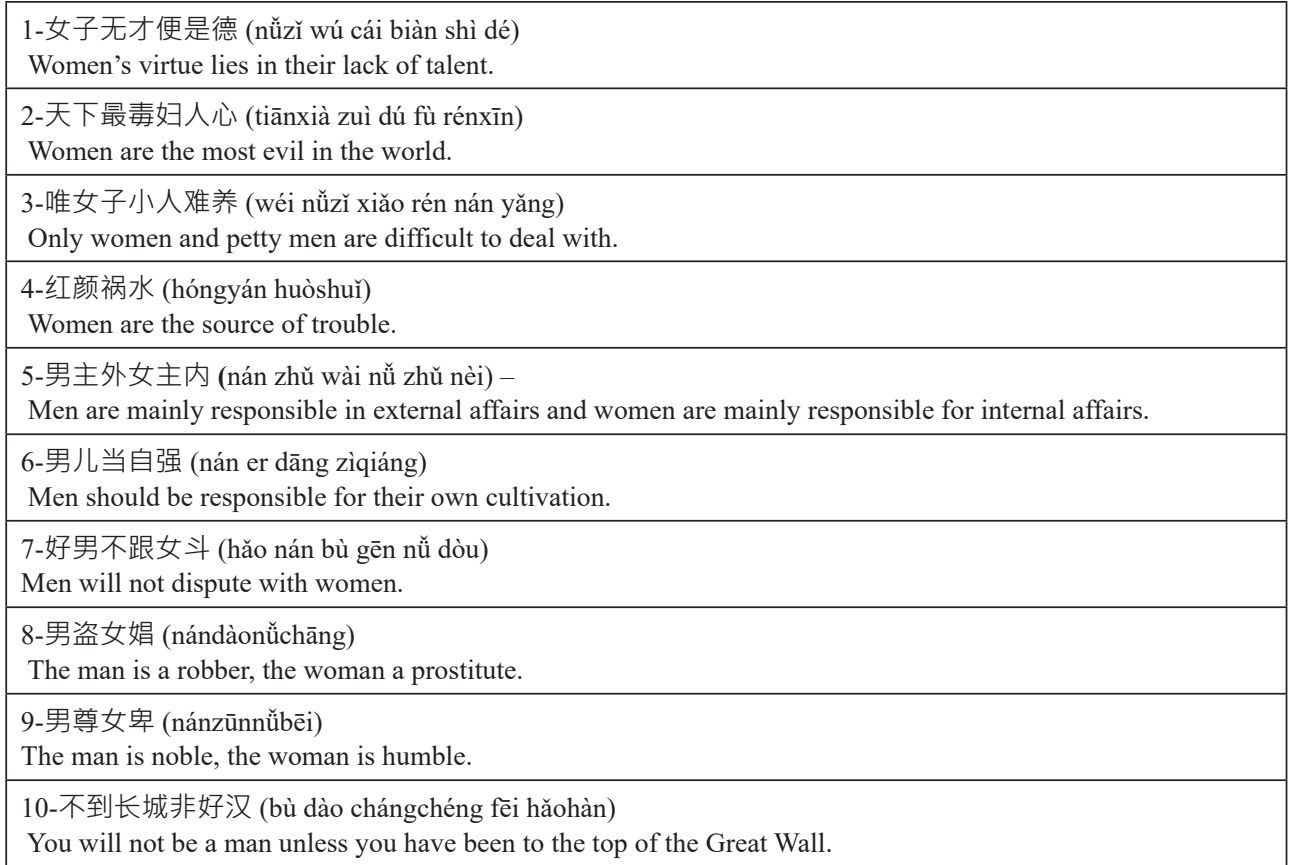

Table 1. The most written idioms and proverbs by students.

As can be seen from the table, while examples 6 and 10 are only about men, the $1^{\text {st }}, 2^{\text {nd }}$ and $4^{\text {th }}$ examples are solely about women. When we look at the examples most frequently written by students, we see that there are ones related to women. What is important here is how the selected examples define women. Selected proverbs and idioms about men reveal the power and dominance of men, while the examples chosen for women define the woman as obedient to her husband at home.

As evident in the analysis, the proverbs and idioms above projects women's obedience, weakness and deficient characteristics as positive attributes. This survey gives a worrying result, especially considering that the majority of the students were women and well-educated. Well-educated students are expected to be better aware of gender equality and the status of women. However, the selected idiomatic examples do not confirm this.

Besides these proverbs and idioms, there are some idioms and proverbs carrying negative meanings and demeaning ideas about women in the Chinese language. A good example of this is 夫唱妇随 (fū chàng fù suí) which means that the husband sings and the wife follows. This proverb teaches women how to be a "good" wife. Other proverbs and idioms give us an idea of the subordinate role of women in marriage in China. The idiom 相女配夫 (xiāng nü pèi fū) means that women are selected by men. The proverb 女人嫁汉, 穿衣吃饭 (nürén jià hàn chuānyī chīfàn) means when women are married, they have clothes and food. Based on 
these examples, it is thought that the woman does not have the right to speak before or after marriage. In addition to this, she is supposed to financially depend on her husband. Another proverb that gives a negative impression of women is 三个女人一个噓 (sān gè nürén yīgè $x \bar{u})$. It means three women makes a crowd and depicts women as being noisy, gathering together and gossiping.

As can be seen from the examples, sexist attitudes, traditional thought and social inequities are reflected in the idioms and proverbs of the Chinese language. ${ }^{20}$ They clearly reveal the submissive role of women in marriage and the secondary place of them in society.

\section{4- The Third-Person Singular Pronouns 他 (tā) and 她 (tā)}

In the Chinese language, the third-person pronoun 他 (tā) is composed of the radical 人 (rén), meaning people, which is an epicene (gender-neutral). It could in fact refer to he, she or it. Until the early 20th century there was no third-person feminine pronoun in Chinese. The female pronoun was required when translations between Chinese and Western languages began and the usage of 他 (tā) started to cause some problems for some Chinese scholars. When "she" was translated into Chinese, it also used 他 (tā) and this caused some ambiguity. After the May 4th Movement of 1919, the Chinese character 她 (tā), for the third-person feminine singular pronoun, was invented. In 1920 there were three different pronouns for “他”: 他 (tā), 她 (tā), and 它 (tā) referring to male, female and neutral third-person, respectively. ${ }^{21}$ A great deal of debate has arisen since the use of the "她” (tā) character began. Some scholars have debated whether the invention of a new character was necessary, while others have debated why the male pronoun's character remained the same 他 (tā). The character 他 (tā) represented both people in general and the male third-person pronoun, while 她 (tā) just represented the female third-person pronoun. Then some writers proposed another new character composed by the combination of 男 and 也. However, this character never reached the widespread popularity of 她 (tā).22 Yuanzheng Ling explains why this character failed:

"Since the third-person pronoun in Chinese was originally genderless, there was an objective need to create feminine and neutral characters 她 and 它 for the third-person singular. Thus, there was no need to denote masculinity; and since there was no need for such a character, to create one naturally would have been superfluous. ${ }^{23}$

20 Wing B. A.Tso, "Masculine Hegemony and Resistance in Chinese Language", Writing from Below, 2/1 (2014), p. 8 .

21 Gang Zhao, "The Cultural History of the Chinese Character "ta" (the third-person feminine pronoun)", East Asian History and Culture Review, 2009, pp. 218-220. https://cross-currents.berkeley.edu/sites/default/files/ejournal/articles/reading/zhao.pdf (Accessed on 18 September 2020)

22 David Moser, "Covert Sexism in Mandarin Chinese", Sino-Platonic Papers, 1997, p. 11.

23 Yuanzheng Ling 远征凌, “Tazi de chuangzao lishi 《“她” 字的创造历史》(“The History of the Character “ Ta”她”)”, Language Teaching and Research <语言教学与研究>, 1989, pp. 139-151 
As can be seen from the failure of the use of the 男也 character, women were linguistically relegated to a special class. ${ }^{24}$ While this female-male third-person pronoun distinction was not required in spoken language, it was, however, used in written language.

\section{Conclusion}

As long as there are sexist thoughts in a society, they will be reflected in the language and will continue to be transferred from generation to generation through words. ${ }^{25}$ Gender differentiation in language originates from a range of different forms. The above examples demonstrate that some features of contemporary Chinese language reflect male-dominated social attitudes and women's inferior position still present in Chinese society. ${ }^{26}$ Socialist reforms of the PRC period made some attempts to eliminate sexist idioms and establish an egalitarian language that ensures gender equality among Chinese people, but these attempts had only limited and short-term success. ${ }^{27}$ Despite lacking grammatical gender, there are several ways to state gender related expressions in the Chinese language. Because gender discrimination is done in a covert way in Chinese, it is more difficult to pinpoint. As long as it is not noticed or highlighted, the bad perception of women will continue to exist through language. At this point the question comes to mind: what can be done to raise awareness and eliminate gender inequality in language? The answer to this question might be the topic of another article.

Peer-review: Externally peer-reviewed.

Conflict of Interest: The author has no conflict of interest to declare.

Grant Support: The author declared that this study has received no financial support.

\section{References}

Bańka, Katarzyna. (2015), Gender in Written and Spoken Chinese Language: When the Words Are Masculine and When Feminine?, Frontiers of Language and Teaching, 6, 54-62.

Chan, Marjorie K.M. (1997), "Gender Differences in the Chinese Language: A Preliminary Report”, NACCL-9, Los Angeles:GSIL Publication, 35-52.

Ettner, Charles. 2002, "In Chinese, men and women are equal - or - women and men are equal?" Gender Across Languages: The Linguistic Representation of Women and Men, 2, Ed. Marlis Hellinger and Hadumod Bußmann, Philadelphia: John Benjamins, 27-73.

Fan, Carol C. (1996), "Language, Gender and Chinese Culture”, International Journal of Politics, Culture and Society, 10/1, 95-114.

24 David Moser, "Covert Sexism in Mandarin Chinese", Sino-Platonic Papers, 1997, p. 11.

25 Catherine S. Farris, "Gender and Grammar in Chinese With Implications for Language Universals", Modern China, 1988, p. 282.

26 Charles Ettner, "In Chinese, men and women are equal - or - women and men are equal?" Gender Across Languages: The Linguistic Representation of Women and Men, 2002, p. 50.

27 Ibid., 49. 
Farris, Catherine S. (1988), "Gender and Grammar in Chinese With Implications for Language Universals", Modern China, 14/3, 277-308. Retrieved from https:/www.jstor.org/stable/189320?seq=1\#metadata_info_ tab_contents (Accessed April 11, 2020)

Fidan, Giray. (2011), Çin Dili ve Çince Dilbilgisi, Ankara: Efil Yayınevi, 1-20

Gu, Lihong. (2013), "Language and Gender: Differences and Similarities", Retrieved from https://www. atlantis-press.com/proceedings/asshm-13/10624 (Accessed September 2, 2020.)

Jung-Palandri, Angela. (1991), "Gender and Sexism in Chinese Language and Literature”,Sino-Platonic Papers, 27, 167-170.

Lakoff, Robin. (1973), "Language and Women's Place”, Cambridge University Press, 2/1, 45-80. Retrieved from https://web.stanford.edu/class/linguist156/Lakoff_1973.pdf (Accessed September 12, 2020.)

Li, Tsz Kwan (李子君). (2016), “Chinese is a sexist language’: a re-examination”, City University of Hong Kong.

Ling, Yuanzheng 远征凌. (1989), “Tazi de chuangzao lishi 她” 字的创造历史 (“The History of the Character “Ta'她”)”, Language Teaching and Research 语言教学与研究, 139-151.

Shih, Yu-Hwei. (1984), "Cong she-hui yuyan xue guangdian tantao Zhongwen nannu liang xing yuyan de chayi (A sociolinguistic study of male-female differences in Chinese", Jiao xue yu yanjiu, College of Arts: National Taiwan Normal University, 207-229

Moser, David. (1997), "Covert Sexism in Mandarin Chinese”, Sino-Platonic Papers, 1-23. Retrieved from http://sino-platonic.org/complete/spp074_chinese_sexism.pdf (Accessed September 8, 2020)

Tan, Dali. (1990), "Sexism in the Chinese Language”, NWSA Journal, 2/4, 635-639.

“Traditional Chinese Character", http://www.hanban.com/writing-chinese/characters/traditional-chinesecharacter.html (Accessed September 12, 2020)

Tso, Wing B. A. (2014), "Masculine Hegemony and Resistance in Chinese Language", Writing from Below, $2 / 1,1-15$.

Yun, Zhang. (2009), "A Cultural History of the Chinese Character "Ta" (She)—On the invention and identification of a new female pronoun (“她”字的文化史一女性新代词的发明与认同研究”)”, by Huang Xingtao 黄 兴涛. Review, Fuzhou: Fujian jiaoyu chubanshe.

Zhao, Gang. (2009), "The Cultural History of the Chinese Character "ta" (the third-person feminine pronoun)", East Asian History and Culture Review, 218-220. Retrieved from https://cross-currents.berkeley.edu/sites/ default/files/e-journal/articles/reading/zhao.pdf (Accessed September 18, 2020)

Wu, Jianhsin. (2016), "Basic Radicals", In The Way of Chinese Characters, Retrieved from https://www.chengtsui.com/sites/default/files/previews/Way\%20of\%20Chinese\%20Characters_2E_Sample.pdf (Accessed September 10, 2020)

(2008), “Gender-specific Asymmetries in Chinese Language”, MP: An Online Feminist Journal, 31-41. Retrieved from http://academinist.org/wp-content/uploads/2008/07/xiaoping.pdf (Accessed March 22, 2018.) 